\title{
LACTOSE HYDROLYSIS IN DIFFERENT SOLIDS CONTENT WHEY AND MILK PERMEATES
}

\author{
Kristine Zolnere*, Inga Ciprovica \\ Department of Food Technology, Faculty of Food Technology, Latvia University of Life Sciences and Technologies, \\ Rìgas iela 22, Jelgava, Latvia, e-mail: k.zolnere@gmail.com
}

\begin{abstract}
Dairy permeates contain almost original amount of lactose, small fraction of other solid compounds and water. For complete lactose hydrolysis and glucose-galactose syrup production, it is essential to ensure the optimal substrate concentration and conditions to improve product quality and save energy, water and material costs. The aim of this study was to investigate $\beta$-galactosidase preparates capability using concentrated whey and milk permeates with 20,30 and $40 \%\left(\mathrm{w} \mathrm{w}^{-1}\right)$ of total solids. Commercial $\beta$-galactosidase preparates (Ha-Lactase 5200 produced by Kluyveromyces lactis and NOLA Fit5500 produced by Bacillus licheniformis, Chr.HANSEN; GODO-YNL2 produced by Kluyveromyces lactis, Danisco, Denmark) at dosage $500 \mathrm{NLU} \cdot \mathrm{L}^{-1}$ (Ha-Lactase 5200 , GODO-YNL2) and 500 BLU. $L^{-1}$ (NOLA Fit5500) were used for lactose hydrolysis. The concentration of each permeate was 20,30 and $40 \%\left(\mathrm{w} \mathrm{w}^{-1}\right)$ of total solids. $10 \% \mathrm{KOH}$ was used to adjust optimal $\mathrm{pH}$ for fermentation media. Samples were monitored in incubator for 4 hours at temperature $42.5 \pm 0.5^{\circ} \mathrm{C}$. Lactose, glucose and galactose concentrations were determined by HPLC (Shimadzu LC -20 Prominence, USA). Ha-Lactase 5200 preparate was able to increase lactose hydrolysis rate more than $90 \%$ in all permeates at $20 \%$ and $30 \%$ solids concentration. GODO-YNL2 preparate showed the highest conversion of glucose in sweet whey permeate at $20 \%$ solids concentration and the lowest conversion of galactose in sweet whey permeate at $30 \%$ solids concentration. The results indicated that substrate type and solids concentration have an effect on the relative activity of commercial enzymes. The study results give a greater understanding about permeates suitability for glucose-galactose syrup production.
\end{abstract}

Keywords: lactose hydrolysis, glucose-galactose syrup, permeate, $\beta$-galactosidase

\section{Introduction}

In food industry, carbohydrate plays an important role in production, in nutritional value of product and is an important factor of sweet taste formation (Evdokimov et al., 2015). Hydrolysis of lactose into monosaccharides gives several advantages that have been appreciated by the food industry. Final product has higher sweetness and solubility, contains diverse types of monosaccharide at different concentration. Lactose can be enzymatically hydrolysed using $\beta$-galactosidase which produced from GRAS microorganisms or chemically hydrolysed with acids and ion-exchange resins (Illanes, 2016). Hydrolysis of lactose at range of 50 to $90 \%$ in concentrated whey and permeate syrup increases sweetness and prevents lactose crystallization during evaporation process, planning to reach $60-70 \%$ of solids in concentrated whey (Macwan et al., 2016). Products can be used for invention of innovative and low calorie syrups with high sweetness (Rhimi et al., 2010). One of the perspective applications of lactose is glucose-galactose syrup production by enzymatic hydrolysis. Syrup is viscous, thick sugar solution containing approximately $20 \%$ of water, $68 \%$ of glucose and galactose, $11 \%$ of lactose and $1 \%$ of minerals (Lindsay et al., 2018). Glucose-galactose syrup characterises with a sweet taste, dark yellow colour, transparency, good solubility (Budriene et al., 2005) and it might be used as sucrose substitute. Milk and whey permeates are valuable sources for enzymatical lactose hydrolyse (Ryan, Walsh, 2016). Industries prefer to hydrolyse lactose using free enzyme however, the immobilization of $\beta$-galactosidase begins to draw the attention of producers. The ability to efficiently hydrolyse whey lactose is one of the key factors determining overall process economy (Vasileva et al., 2016). The aim of this study was to investigate $\beta$-galactosidase preparates for fermentation capability using concentrated whey and milk permeates with 20 , 30 and $40 \%\left(\mathrm{w} \mathrm{w}^{-1}\right)$ of total solids.

\section{Materials and Methods \\ Chemicals and materials}

Acetonitrile (HPLC grade, $\geq 99.93 \%$ purity), column SUPELCOSIL ${ }^{\mathrm{TM}}$ LC-NH $2,(250 \mathrm{~mm} \times 4.6 \mathrm{~mm} \times 5 \mu \mathrm{m})$, D-lactose monohydrate ( $\geq 99.5 \%$ purity), $\mathrm{D}(+)$ galactose ( $\geq 99 \%$ purity), $\mathrm{D}(+)$ glucose ( $\geq 99.5 \%$ purity), $\mathrm{KOH}$ $(\geq 85 \%$, pellets) were purchased from Sigma-Aldrich. Sweet whey permeate was donated by SC "Smiltenes piens", but whey and milk permeates were obtained from SC "Tukuma piens".

Enzymes

Three commercial $\beta$-galactosidase preparates HaLactase 5200 produced by Kluyveromyces lactis, activity $5200 \mathrm{NLU} \cdot \mathrm{g}^{-1}$ and NOLA Fit5500 produced by Bacillus licheniformis, activity $5500 \quad \mathrm{BLU} \cdot \mathrm{g}^{-1}$ (Chr.HANSEN, Denmark) and GODO-YNL2 produced by Kluyveromyces lactis, activity $5000 \mathrm{NLU} \cdot \mathrm{g}^{-1}$ (Danisco, Denmark) were used in the present study.

\section{Solids concentration}

Solids concentration of permeates was performed by Chandrapala et al. (2016) method with some modifications. The concentration of permeates solids was accomplished using pilot scale evaporation FT 22 (Armfield, UK) under vacuum conditions to achieve approximately $20 \%\left(\mathrm{w} \mathrm{w}^{-1}\right)$ of solids. Evaporation conditions were as follows: flow rate $8 \mathrm{~L} \mathrm{~h}^{-1}$, warming steam pressure 1 bar, permeate temperature $78 \pm 1^{\circ} \mathrm{C}$, cooling water rate $5 \mathrm{~L} \mathrm{~h}^{-1}$, and vacuum 0.56 bar. Rotary vacuum evaporator Laborota 4000 efficient (Heidolph, Germany) was used to reach permeates solids concentration $30 \% \quad\left(\mathrm{w} \mathrm{w}^{-1}\right)$ and $40 \% \quad\left(\mathrm{w} \mathrm{w}^{-1}\right)$. 
Refractometer 30GS Mettler (Toledo, Japan) was used for permeates solids determination.

\section{Permeates hydrolysis}

Experiments were carried out based on Dutra Rosolen et al. (2015) method with some modification. Commercial enzyme weighted into $100 \mathrm{~mL}$ conical flasks and $50 \mathrm{~mL}$ permeate added with an appropriate $\mathrm{pH}$. All substrate $\mathrm{pH}$ for hydrolysis with Ha-Lactase 5200 enzyme was adjusted till 6.5-6.7, for NOLA Fit5500 enzyme 5.4-5.8 and for GODO-YNL2 enzyme 7.5-7.7. 10\% KOH was used to adjust an optimal medium $\mathrm{pH}$ for enzymatic hydrolysis. Triplicate experiments were prepared for each type of permeate.

The dosage of commercial enzymes for permeate lactose hydrolysis is summarized in Table 1.

Table 1

Summary of added enzymes (mean values \pm SD $(n=3)$ )

\begin{tabular}{lcc}
\hline Enzyme preparate & Weight, mg & Unit \\
\hline Ha-Lactase 5200 & $53.2 \pm 2.5$ & $292 \pm 13 \mathrm{NLU} \cdot \mathrm{g}^{-1}$ \\
NOLA Fit5500 & $52.1 \pm 2.1$ & $270 \pm 11 \mathrm{BLU} \cdot \mathrm{g}^{-1}$ \\
GODO-YNL2 & $53.6 \pm 2.2$ & $268 \pm 12 \mathrm{NLU} \cdot \mathrm{g}^{-1}$ \\
\hline
\end{tabular}

Samples were fermented at temperature $42.5 \pm 0.5^{\circ} \mathrm{C}$ 4 hours. Fermented samples were put in water bath and heated at $80{ }^{\circ} \mathrm{C} 5 \mathrm{~min}$ for enzyme inactivation. Samples were transferred into $50 \mathrm{~mL}$ test tubes and placed into freezer at $-18{ }^{\circ} \mathrm{C}$ for further analyses.

\section{HPLC analysis}

Lactose, glucose and galactose was determined according to method which was used in Žolnere et al. (2018) work with some modifications.

Sample preparation: samples were transferred into $2 \mathrm{~mL}$ test tube and centrifuged $5 \mathrm{~min}$ at $10000 \mathrm{rpm}$. Approximately $1.5 \mathrm{~mL}$ of filtered sample was placed into sampler vials and sealed for HPLC analysis. HPLC (Prominence HPLC system, Shimadzu LC-20, Torrance, CA, USA) was used for sugar determination, refractive index detector RID-10A; column SUPELCOSIL $^{\mathrm{TM}}$ LC-NH2, $(25 \mathrm{~cm} \times 4.6 \mathrm{~mm}) 5 \mu \mathrm{m}$ column; $35^{\circ} \mathrm{C}$ temperature; gradient mobile phase acetonitrile: deionized water $(80: 20)$; volume of the injected sample: $10 \mu \mathrm{L}$; total analysis time of up to

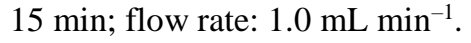

\section{Data analysis}

Results were expressed as mean \pm standard deviation (SD) of three replicates for composition measurements. Statistical analyses were carried out using One-Way ANOVA and Tukey test. Differences were considered statistically significant when $\mathrm{p}<0.05$.

\section{Results and Discussion}

Sweet whey permeate $\mathrm{pH}$ in all solids concentration was in range of 5.8-6.1, acid whey permeate 4.4-4.8 and milk permeate 5.5-5.8. According to specification of enzyme preparates for Ha-Lactase 5200 optimal medium $\mathrm{pH}$ is range of 6.5 to 8.0, NOLA Fit5500 of 5.4 to 7.0 and for GODO-YNL2 from 7.5 to 8.0 (Žolnere et al., 2018).

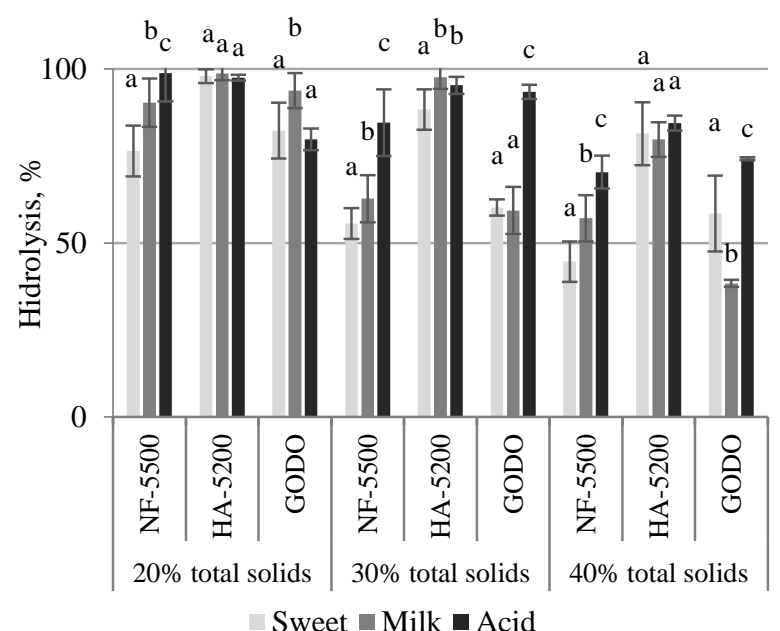

Figure 1. The comparison of analysed commercial enzymes activity in permeates at different solids concentration

*Results indicated with the same letter do not differ significantly $(\mathrm{p}>0.05)$

NF-5500 - NOLA Fit5500 enzyme, HA-5200 - Ha-Lactase 5200 enzyme, GODO - GODO-YNL2 enzyme

The highest percentage of hydrolysis (97.5-98.8\%) showed Ha-Lactase 5200 enzyme in all permeates at $20 \%\left(\mathrm{~W} \mathrm{w} \mathrm{w}^{-1}\right)$ solids concentration. Similar results we noticed at $30 \%\left(\mathrm{w} \mathrm{w}^{-1}\right)$ and $40 \%\left(\mathrm{w} \mathrm{w}^{-1}\right)$ solids concentration (hydrolyse percentage ranged from 88.3 to $97.6 \%$ and $79.7-84.5 \%$, respectively). Other enzymes had showed several results at different solids concentration. The solids concentration can be one of the factor, which influenced NOLA Fit5500 and GODO-YNL2 enzymes activity than for Ha-Lactase 5200 enzyme.

Permeate composition may affect the enzyme activity. Addition of potassium ions during substrate $\mathrm{pH}$ adjustment may influence enzyme activity as well. According Jurado et al. (2004) data, metal ions affect the stability and activity of $\beta$-galactosidase. The main monovalent ions activator is $\mathrm{K}^{+}$for Kluyveromyces lactis $\beta$-galactosidase but $\mathrm{K}^{+}$and $\mathrm{Na}^{+}$for Bacillus licheniformis $\beta$-galactosidase (Juajun et al., 2011; Jurado et al., 2004). For hydrolysis with Ha-Lactase 5200 and GODO-YNL2 was necessary to add $10 \%$ $\mathrm{KOH}$ to all permeates but for hydrolysis with NOLA Fit5500 it was required to add alkali only for acid whey permeate samples. Hydrolysis results with NOLA Fit5500 enzyme showed that acid whey permeate samples, where $10 \% \mathrm{KOH}$ was added, performed the highest hydrolyse percentage in all 3 solid concentrations. Its approved $\mathrm{K}^{+}$ion positive influence on Bacillus licheniformis $\beta$-galactosidase activity. Evaluating Ha-Lactase 5200 and GODO-YNL2 enzymes, the lower optimal $\mathrm{pH}$ level is 6.5 and 7.0, respectively, which needs to be adjusted. The addition of $10 \% \mathrm{KOH}$ differs, more alkali was added to optimized GODO-YNL2 enzyme activity in all 
permeates samples which leads to increased $\mathrm{K}^{+}$ion concentration in substrate and influenced the enzyme activity and lactose hydrolysis capability.

Figure 2 illustrates the amount of glucose and galactose in permeates at $20 \%\left(\mathrm{w} \mathrm{w}^{-1}\right)$ solids concentration. Results showed that almost all hydrolyse reactions finished with higher glucose amount but as the exception were acid whey permeate sample with NOLA Fit5500 enzyme (glucose $65.4 \mathrm{~g} \mathrm{~L}^{-1}$, galactose $70.1 \mathrm{~g} \mathrm{~L}^{-1}$ ). Sweet whey and milk permeates hydrolysis results showed that there is no significant difference between galactose amount using different $\beta$-galactosidase preparates. Reported by Harju et al., (2012) lactose hydrolysis of $70 \%$ in dairy product increases sweetness by an amount corresponding to an addition of approximate $2 \%$ sucrose. The hydrolysis of lactose into glucose and galactose increase product sweetness because glucose has higher sweetness level than lactose (Pruksasri, 2015). It's reflected also on results where almost all samples showed higher glucose concentration which means samples sweetness at the end were higher than at the beginning of hydrolysis reaction.

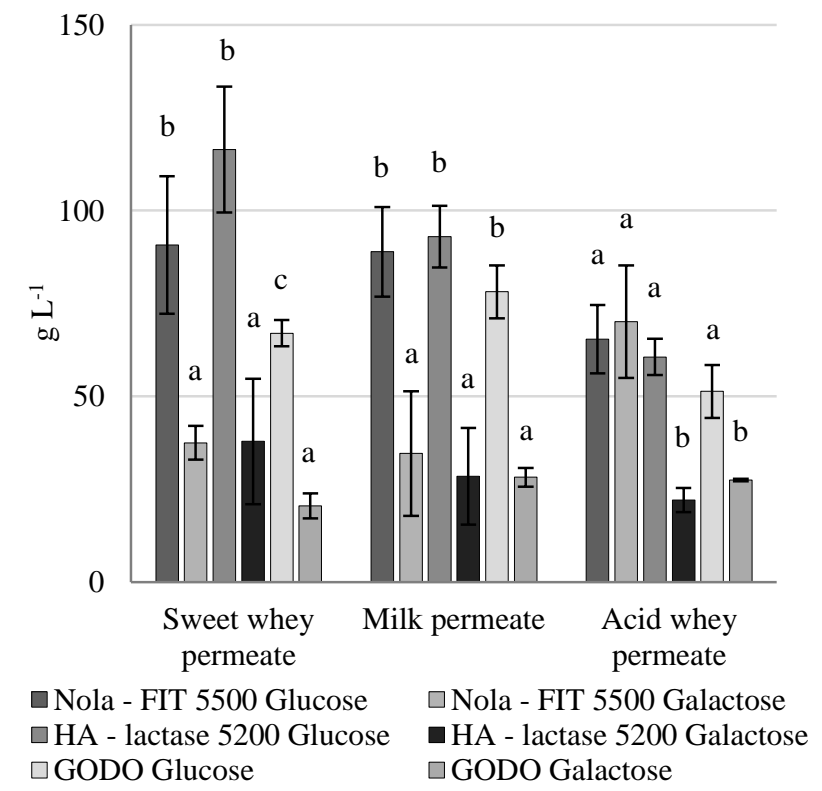

Figure 2. Amount of glucose and galactose in permeates at $20 \%\left(\mathrm{w} \mathrm{w}^{-1}\right)$ solids concentration

*Results indicated with the same letter between one type of monosaccharide in certain permeate do not differ significantly $(\mathrm{p}>0.05)$.

Glucose and galactose amount in permeates at 30\% $\left(\mathrm{w} \mathrm{w}^{-1}\right.$ ) solids concentration (Figure 3) was within results showed in Figure 2. The monosaccharides outcome from all enzyme preparates was quite close. Results indicated that activity of enzyme preparates had affected permeates composition and physical-chemical indices. The hydrolysis of lactose by NOLA Fit5500 enzyme did not show similar outcome results with the hydrolysis of other enzyme preparates. It should be highlighted that in the reaction was used preparates with $\beta$-galactosidase from different sources and were used three substrates, which were compared.

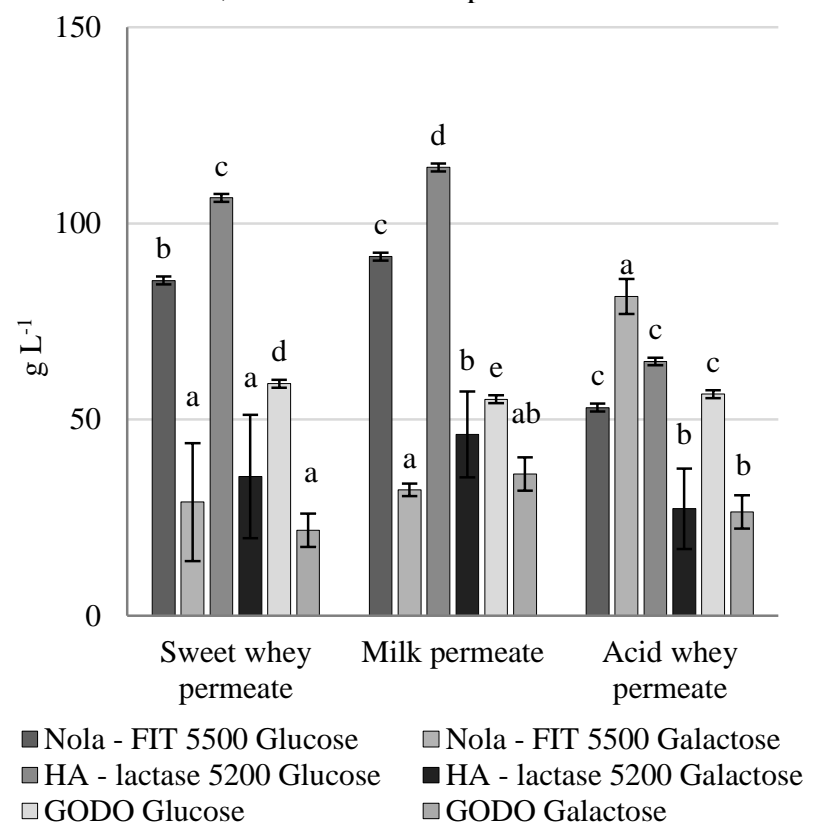

Figure 3. Amount of glucose and galactose in permeates at $30 \%\left(\mathrm{w} \mathrm{w}^{-1}\right)$ solids concentration

* Results indicated with the same letter between one type of monosaccharide in certain permeate do not differ significantly $(\mathrm{p}>0.05)$.

The hydrolysis of microbial enzyme Bacillus licheniformis properties has not been fully studied therefore, there is a need for numerous studies to obtain a better knowledge of gained results. As it was reported by Božanić et al. (2014) acid whey contains higher amount of the calcium, phosphate, lactic acid and lactate than it is in sweet whey. These could be considered as the main factors, which affects the effectiveness of this particular enzyme activity to hydrolyse lactose in acid whey.

The results in Figure 4 indicated that the amount of glucose and galactose was lower comparing with the results from Figure 2 and 3. It can be approved with the hydrolysis percentage of permeates at $40 \%\left(\mathrm{w} \mathrm{w}^{-1}\right)$ solids concentration (see in Figure 1). The cause of low lactose hydrolysis might be that $\beta$-galactosidase activity was decreased by the high lactose concentration in $40 \%$ $\left(\mathrm{w} \mathrm{W}^{-1}\right)$ solids concentrate permeates and the presence of glucose and galactose. According to Demirhan et al. (2008) study glucose and galactose at concentration $10.32 \mathrm{~g} \mathrm{~L}^{-1}$ and $13.03 \mathrm{~g} \mathrm{~L}^{-1}$, respectively, start acting as inhibitors slowing down lactose hydrolysis reaction. As an option for complete lactose hydrolysis of permeates at $40 \%\left(\mathrm{w} \mathrm{w}^{-1}\right)$ solids concentration would be time extension for reaction.

$\beta$-Galactosidase activity may affect several factors, such as temperature, $\mathrm{pH}$, pressure, concentration of substrate and presence of metal ions (Bosso et al., 2016). The study results showed that addition of $10 \% \mathrm{KOH}$ influenced lactose hydrolysis and new carbohydrates formation. 


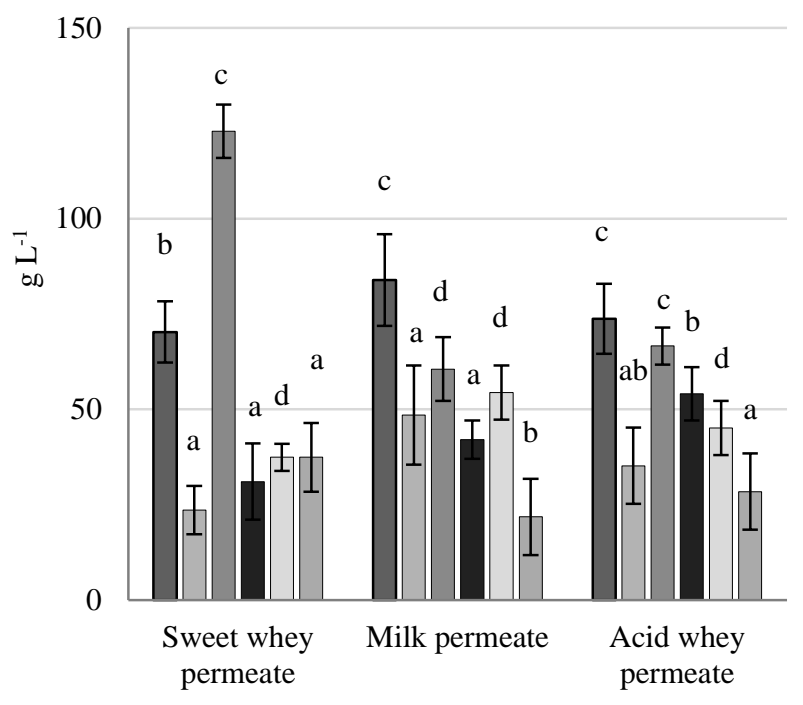

口Nola - FIT 5500 Glucose $\square$ HA - lactase 5200 Glucose $\square$ GODO Glucose

$\square$ Nola - FIT 5500 Galactose

- HA - lactase 5200 Galactose $\square$ GODO Galactose

Figure 4. Amount of glucose and galactose in permeates at $40 \%\left(\mathrm{w} \mathrm{w}^{-1}\right)$ solids concentration

*Results indicated with the same letter between one type of monosaccharide in certain permeate do not differ significantly $(\mathrm{p}>0.05)$.

Mariyani et al. (2015) had reported that in the situation when after lactose hydrolysis the galactose concentration was lower than glucose that might be associated to the development of galactooligosaccharides. The substrate for hydrolysis containing highly concentrated lactose, $\beta$-galactosidase is able to produce galacto-oligosaccharides and affect the final concentration of glucose and galactose. As stated by Suárez et al. (2018), glucose and galactose are being produced equimolar, while lactose concentration decreases slowly and water (as a nucleophile) activity is high. However, when lactose concentration keeps be high, activity of water is low and lactose starts to act as nucleophile and transgalactosylation become more active and starts producing galactooligosaccharides. This statement can explain the relation between glucose and galactose results in this study.

\section{Conclusions}

These results provide more accurate information in which substrates the commercial enzyme is able to hydrolyse lactose to a maximal extent. Each substrate at certain concentration has different physical and chemical properties which influence enzyme activity and profile of final outcome. Use of $\mathrm{KOH}$ for medium $\mathrm{pH}$ control can be evaluated positively because it works as activator for enzyme. Almost all of the results showed that after lactose hydrolysis the dominant monosaccharide was glucose. The obtained results can be used in further research to work on glucose-galactose syrup production technology.

\section{Acknowledgment}

The research was supported by project 'Strengthening Research Capacity in the Latvia University of Agriculture'. Contract No. 3.2.-10/2017/LLU/27.

\section{References}

1. Bosso A., Morioka L. R. I., Santos L. F., Suguimoto H. H. (2016) Lactose hydrolysis potential and thermal stability of commercial $\beta$-galactosidase in UHT and skimmed milk. Food Science and Technology, Vol. 36, p. 159-165.

2. Božanić R., Barukčić I., Lisak K. (2014) Possibilities of whey utilisation. Journal of Nutrition and Food Sciences, Vol. 2, p. 1-7.

3. Budriene S., Gorochovceva N., Romaskevic T., Yugova L. V., Miezeliene A., Dienys G., Zubriene A. (2005) $\beta$-galactosidase from Penicillium canescens. Properties and immobilization. Central European Journal of Chemistry, Vol. 3, p. 95-105.

4. Chandrapala J., Wijayasinghe R., Vasiljevic T. (2016) Lactose crystallization as affected by presence of lactic acid and calcium in model lactose systems. Journal of Food Engineering, Vol. 178, p. 181-189.

5. Demirhan I. N., Kilic D., Ozbek B. (2008) Product inhibition of whey lactose hydrolysis. Chemical Engineering Communications, Vol. 195, p. 293-304.

6. Dutra Rosolen M., Gennari A., Volpato G., Volken De Souza C. F. (2015) Lactose hydrolysis in milk and dairy whey using microbial $\beta$-galactosidases. Enzyme Research, Vol. 2015, p. 1-7.

7. Evdokimov I., Somov V., Kurash Y., Perminov S., Knyazev S. (2015) Application of whey-derived syrups in dairy products. Foods and Raw Materials, Vol. 3, p. 89-95.

8. Harju M., Kallioinen H., Tossavainen O. (2012) Lactose hydrolysis and other conversions in dairy products: Technological aspects. International Dairy Journal, Vol. 22, p. 104-109.

9. Illanes A. (2016). Lactose: Production and Upgrading. In: Lactose - derived prebiotics. A. Illanes, C. Guerrero, C. Vera, L. Wilson, R. Conejeros, F. Scott (eds.). Elsevier, p. 1-33.

10. Juajun O., Nguyen T. H. H., Maischberger T., Iqbal S., Haltrich D., Yamabhai M. (2011) Cloning, purification, and characterization of $\beta$-galactosidase from Bacillus licheniformis DSM 13. Applied Microbiology and Biotechnology, Vol. 89, p. 645-654.

11. Jurado E., Camacho F., Luzón G., Vicaria J. M. (2004) Kinetic models of activity for $\beta$-galactosidases: Influence of $\mathrm{pH}$, ionic concentration and temperature. Enzyme and Microbial Technology, Vol. 34, p. 33-40.

12. Lindsay M. J., Walker T. W., Dumesic J. A., Rankin S. A., Huber G. W. (2018) Production of monosaccharides and whey protein from acid whey waste streams in the dairy industry. Green Chemistry, Vol. 20, p. 1824-1834.

13. Macwan S. R., Dabhi B. K., Parmar S. C., Aparnathi K. D. (2016) Whey and its utilization. International Journal of Current Microbiology and Applied Sciences, Vol. 5, p. 134-155.

14. Mariyani N., Faridah D. N., Khusniati T., Lioe, H. N. (2015) Hydrolysis of UHT milk lactose by partially purified crude enzyme of $\beta$ - galactosidase obtained from Lactobacillus plantarum B123 indigenous strain. International Food Research Journal, Vol. 22, p. 2274-2279.

15. Pruksasri S. (2015). Dairy stream lactose fractionation/concentration using polymeric ultrafiltration 
membrane. In: Membrane processing for dairy ingredient separation. K. Hu, J. Dickson (eds.). Wiley-Blackwell, p. 35-66.

16. Rhimi M., Boisson A., Dejob M., Boudebouze S., Maguin E., Haser R., Aghajari N. (2010) Efficient bioconversion of lactose in milk and whey: Immobilization and biochemical characterization of a $\beta$-galactosidase from the dairy Streptococcus thermophilus LMD9 strain. Research in Microbiology, Vol. 161, p. 515-525.

17. Ryan M. P., Walsh G. (2016) The biotechnological potential of whey. Reviews in Environmental Science and Biotechnology, Vol. 15, p. 1-20.

18. Suárez S., Guerrero C., Vera C., Illanes A. (2018) Effect of particle size and enzyme load on the simultaneous reactions of lactose hydrolysis and transgalactosylation with glyoxyl-agarose immobilized $\beta$-galactosidase from Aspergillus oryzae. Process Biochemistry, Vol. 73, p. $56-64$

19. Vasileva N., Ivanov Y., Damyanova S., Kostova I., Godjevargova T. (2016) Hydrolysis of whey lactose by immobilized $\beta$-galactosidase in a bioreactor with a spirally wound membrane. International Journal of Biological Macromolecules, Vol. 82, p. 339-346.

20. Žolnere K., Ciproviča I., Ķirse A., Cinkmanis I. (2018) A study of commercial $\beta$-galactosidase stability under simulated in vitro gastric conditions. Agronomy Research, Vol. 16, 1555-1562. 